\title{
Effect of soil preparation method on root development of $P$. sylvestris and $P$. abies saplings in commercial forest stands
}

\author{
Santa Celma ${ }^{1}$ - Katrīna Blate ${ }^{1} \cdot$ Dagnija Lazdiṇa $^{1} \cdot$ Kārlis Dūmiṇš $^{1}$ • \\ Santa Neimane ${ }^{1} \cdot$ Toms A. Štāls ${ }^{1} \cdot$ Kristīne Štikāne $^{1}$
}

Received: 19 December 2017 / Accepted: 3 June 2018 / Published online: 8 June 2018

(C) The Author(s) 2018, corrected publication 2020

\begin{abstract}
Soil preparation is a common practice that precedes outplanting of Norway spruce (Picea abies) and Scots Pine (Pinus sylvestris) in boreal forests. It has been proven to enhance the survival and early growth of seedlings. Containerized P. abies and P. sylvestris saplings were excavated 1-3 years after outplanting in clear cut forests across Latvia. The excavated saplings were grown in forests that had been prepared either using site mounding or disc trenching soil preparation method. The aim was to determine the effects of soil preparation method used on the root depth, dry mass and orientation. Saplings are forming deeper root system that expand evenly when planted on mounds, yet the root dry mass was not affected by soil preparation method or soil type. Seedlings planted in trenched sites formed two-sided root system, parallel to the furrow. No correlation between roots growing direction and cardinal points was found.
\end{abstract}

Keywords Mounding $\cdot$ Disc trenching $\cdot$ Root orientation $\cdot$ Forest regeneration

\section{Introduction}

Initial site conditions and early management greatly influence growth, health and productivity of a stand. Therefore it is important to choose management methods that are economically viable and lead to highest productivity in each particular case. Soil preparation prior to planting or sowing is a widely used method to improve seedling survival rate and growth. Soil preparation has shown to improve soil aeration, increase average soil temperature, boost nutrient availability, decrease soil bulk density, decrease competition with surrounding vegetation, as well as reduces the need for tending and to some extent can prevent Hylobius abietis damage (Löf et al. 2012; Luoranen and Viiri 2012; Petersson et al. 2005; Goulet 1995; Örlander et al. 1990). Preparation is typically done

Dagnija Lazdina

dagnija.lazdina@silava.lv

1 Latvian State Forest Research Institute "Silava”, Riga Street 111, Salaspils LV-2169, Latvia 
the year before planting. Disc trenching is currently the most widely used soil preparation method in Latvia. With the help of a disc trencher a furrow is created and soil is pushed to one side, creating a berm on one side of the furrow (Fig. 1). Seedlings are then planted on the hinge of the created microsite. Trenched microsites are believed to be more suitable for forests soils prone to drying out. The positive effect of disc trenching can be enhanced by choosing appropriate trench orientation and planting position which can be either on top of the berm, on the hinge or in the furrow (Burton et al. 2000).

In recent decades mounding has become a more widely used soil preparation method in Northern countries. Mounding is done by excavating soil and turning it over next to the newly made pit. This creates a microsite where mineral soil is exposed on the top of the mound and a double layer of organic soil is created at the bottom. In some cases this can create air pockets between both organic layers, if debris, such as branches, is not properly removed after clearcutting (Haeussler 1989). The pit collects excess water which is often present under climate conditions in Latvia. Due to increasing precipitation in Northern countries water excessiveness can become a problem of wider scope. The mound pit also serves as a water reservoir during dry periods, although if the recommended size of the mound is exceeded the risk of drought increases, especially in humus rich conditions (Gemmel et al. 1996). Compared to unprepared soil, mounding has proven to promote tree growth by creating a favourable microclimate for seedlings in cool regions (Heiskanen et al. 2013; Nieminen et al. 2012; Pearson et al. 2011; Pennanen et al. 2005; Sutton 1993). Forest stands on mounded sites have also shown to fix more carbon than stands on unprepared soil (Mjöfors et al. 2017). Other authors have found that trees grown on mounds tend to grow taller than the ones planted in trenched sites (Uotila et al. 2010; Saksa et al. 2005). In some cases, trenching has shown to be just as effective as mounding (Luorenen and Rikala 2013). In such cases disc trenching can be favoured over mounding due to the lower initial costs. Planted trees are easier to spot and distinguish from naturally occurring trees in mounded sites, due to the elevation of the microsite. This factor alleviates tending, especially during the early years of a stand.

Picea abies and Pinus sylvestris are the two most economically viable planted tree species for regeneration of forests in Latvia. Different growing condition are requirements for each species and should be taken into account when choosing the most appropriate soil preparation method. The objective of this study was to evaluate early root growth response of $P$. abies and $P$. sylvestris to soil preparation method.

a

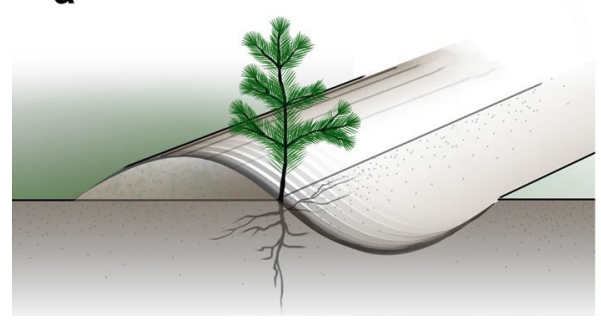

b

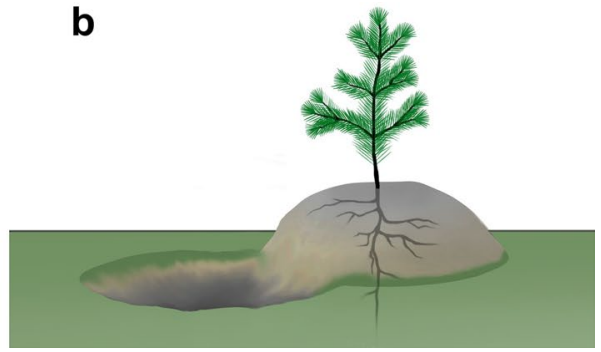

Fig. 1 Planting position when using disc trenching as a soil preparation method (a) and the mounding method (b) 


\section{Materials and methods}

\section{Study sites}

Pinus sylvestris and Picea abies containerized seedlings were measured in forest stands on wet mineral soils (WS) and on drained mineral soils (DS) according to Latvian forest classification system (Zālītis and Jansosns 2013).

All of the studied sites had been prepared for planting by either using mounding (M) or disc trenching (DT) method. Seedlings had been manually planted in the spring of 2013, 2014 and 2015. Respectively — seedlings had spent three, two or one growing season in the planting sites at the time of survey. All study sites were located in the humid continental climate area according to the Köppen climate classification system. Annual total mean precipitation of the region is $667 \mathrm{~mm}$ (of which approximately only $50 \%$ evaporates) and mean temperature is $+5.9^{\circ} \mathrm{C}$.

Containerized seedlings of $P$. abies and $P$. sylvestris were excavated from 45 productive managed forest regeneration sites (Fig. 2). Stands of the same tree species and age were selected in pairs of one trenched and one mounded site of the same forest type. 26 $P$. abies and 19 P. sylvestris stands were surveyed. The study sites were young, regenerated stands managed by Latvian State Forests company and had not been created for research purposes, therefore sites were paired to be as close to each other as practically possible in each particular case. The average distance between sites was 16.2 with a maximum distance of $75.8 \mathrm{~km}$.

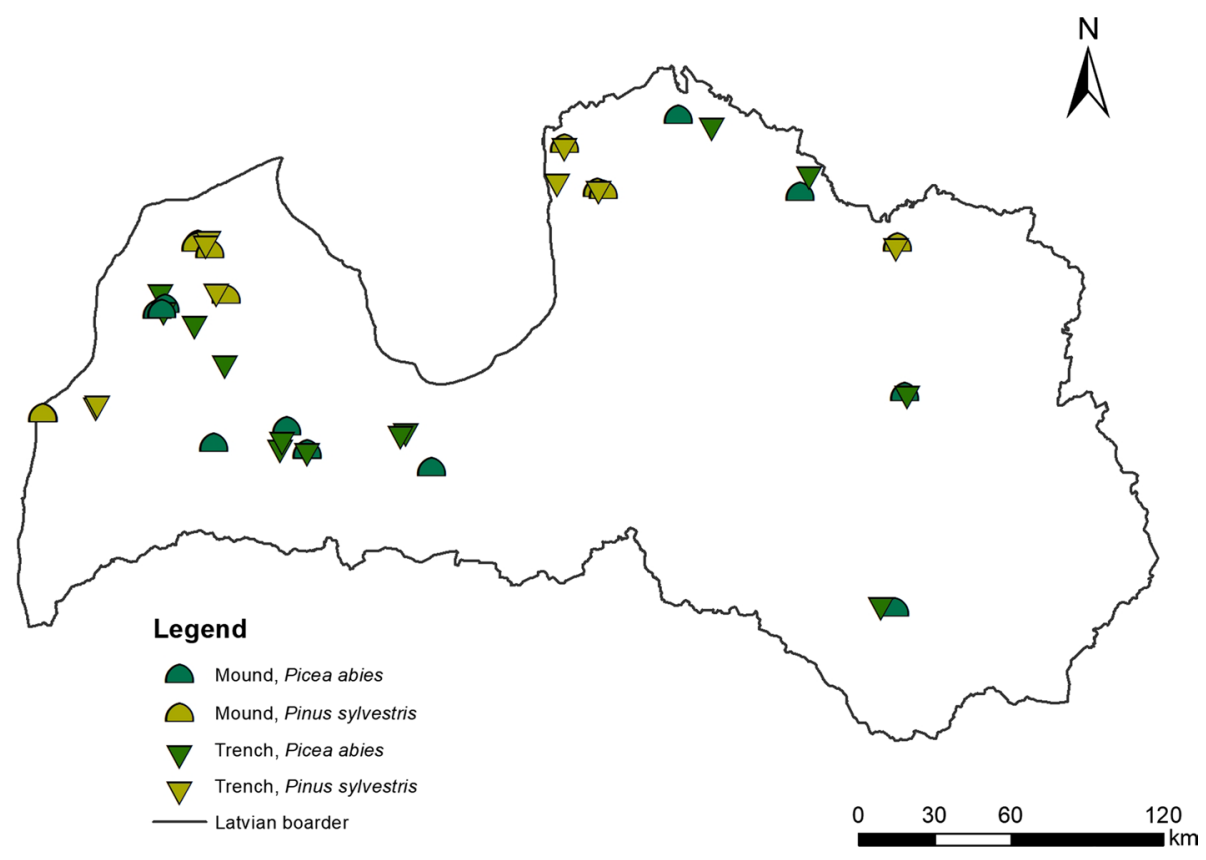

Fig. 2 Location of study sites 
For both soil preparation methods requirements of quality are set by Latvian State Forests. Minimal acceptable width of a mound is $0.50 \mathrm{~m}$, length- $0.60 \mathrm{~m}$ and height- $0.15 \mathrm{~m}$. Mound physical dimensions fit quality requirements in $86.9 \%$ of cases.

Trench furrow quality requirements are depth of $0.15-0.30 \mathrm{~m}$ and width of $0.50-0.70 \mathrm{~m} .76 .0 \%$ of furrows fit the requirement for depth and $65.0 \%$ fit the width requirement (49.4\% of trenches fit both dimension parameters). In most cases where trenches did not fit the requirements, the furrows were shallower and wider than required by standard most likely due to weathering.

\section{Data collection}

Data collection was carried out during the summer of 2016. Five circular plots of $25 \mathrm{~m}^{2}$ (radius $=2.82 \mathrm{~m}$ ) were selected in each study site. Plots were evenly distributed diagonally or in a straight line and the distance between plots was dependant on the dimensions of each individual site.

Tree location in relation to trench or mound pit was noted. In the 2 nd and 4 th plot of each site five healthy trees were carefully excavated (total 10 trees per site). One large, one comparably small and three medium sized trees were manually excavated in order to survey root growth. The root depth and orientation of 1 st and 2 nd order coarse roots in relation to the trench or mound pit was determined. Root area was represented as circular projection that was divided into eight segments (Fig. 3). If any roots fell in such segment, it was noted as 1 , if not, as 0 . Roots falling into each segment were summed up and represented as percentage of total measured tree count. Two of average sized seedling in the 2 nd and 4 th plot were taken to LSFRI Silava to determine seedling root dry mass. The seedlings were dissected at the root collar (where first root starts) and then oven dried after which the root was weighed. Trees that had been notably damaged by grazing or other causes were not used in data analysis. Overall survival of young saplings was high (above 90\%) regardless of soil preparation method. To determine survival dead and alive trees were counted, however, survival rates were not further studied due to empty planting spots that could be a result either of tree dying or due to tree not being planted.

Fig. 3 Schematic representation of root orientation recording method (bold lines in the circle represent roots)

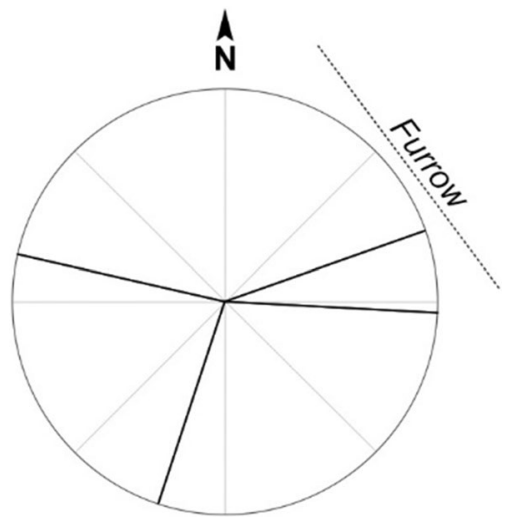




\section{Statistical analysis}

In this study R (R Core Team 2017) version 3.4.1. F and lme4 (Bates et al. 2015) was used to perform a linear mixed effects analysis of the relationship between root depth, root mass and soil preparation method. Planting year and soil preparation method (without interaction) were used as fixed effects in the model. Study site was set as random effect. To compare models and evaluate effect significance ANOVA was used (Fox and Weisberg 2011). Forest type was initially set as fixed effect, but was excluded from the model, since there was no significant difference between model with this effect and a model without the effect in question. Each tree species was looked at separately.

Homoscedasticity of the residuals was determined with Levene Test and visual inspection (Fox and Weisberg 2011), and normality was determined using Shapiro-Wilk test. Data was not normally distributed, therefor it was log-transformed to fit normality assumption.

\section{Results}

\section{Root mass and depth}

Linear mixed-effects model showed that soil preparation method affected root depth of $P$. sylvestris $(P=0.001)$ increasing it in mounded sites (Table 1 and Fig. 4). Soil preparation method did not affect $P$. abies root depth $(P=0.44)$.

There was no correlation between dry root mass and root depth $\left(P\right.$. abies $\mathrm{R}^{2}=0.08, P$. sylvestris $\left.\mathrm{R}^{2}=0.28\right)$. Linear mixed-effects model showed that soil preparation method had no significant effect on dry root mass of both $P$. sylvestris and $P$. abies ( $P=0.60$ and $P=0.09$, respectively).

\section{Root orientation}

No correlation between tree root growth direction and cardinal points was found regardless of tree species, forest type and soil preparation method used. However, it was found that when using disc trenching method both $P$. sylvestris and $P$. abies roots showed a tendency to grow parallel to the furrow (Fig. 5). This was evident already 1 year after outplanting and in later years roots had held this direction and also penetrated deeper into the berm. This does not support the hypothesis that trees develop one sided root system in the direction of berm. It also contradicts an old made claim that furrows would accumulate soil fast enough and therefore provide space for tree roots to grow and establish radial root distribution (Pontey 1808).

Table 1 Results of analysis using general linear mixed effects model with root depth and root dry mass as responsive variables and year and soil preparation method as fixed effects

\begin{tabular}{llrllr}
\hline & & Estimate & SE & $d f$ & \multicolumn{1}{c}{$P$} \\
\hline P. sylvestris depth & Year & -0.347 & 0.045 & 18.768 & $<0.001$ \\
& Soil preparation method & 0.264 & 0.069 & 18.821 & 0.001 \\
P. sylvestris mass & -1.763 & 0.177 & 18.034 & $<0.001$ \\
& Year & 0.147 & 0.279 & 18.100 & 0.603 \\
& Soil preparation method abies depth & -0.260 & 0.075 & 24.169 & 0.002 \\
& Year & 0.068 & 0.088 & 24.577 & 0.44 \\
& Soil preparation method abies mass & -1.131 & 0.200 & 25.321 & $<0.001$ \\
& Year & -0.407 & 0.235 & 25.200 & 0.946 \\
\hline
\end{tabular}



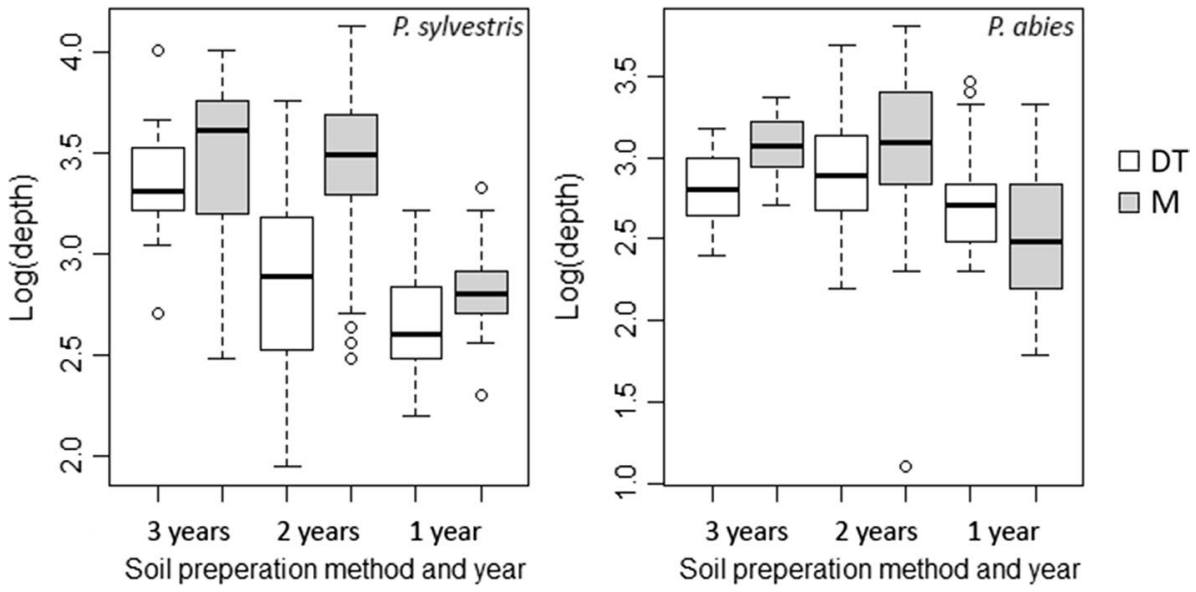

Fig. 4 Pinus sylvestris and Picea abies root depth (log transformed) in disc trenched (DT) and mounded sites (M) depending on tree age (1,2 and 3 years old)

When planted in mounds, tree roots tended to be more evenly radially distributed. Combined with greater root depth, this should lead to more wind resistant forest stands in future. Coarse roots that develop in early age serve as basis for further root development as well as determine their shape and structure.

\section{Discussion}

Already 1 year after outplanting different growth responses of studied trees to soil preparation methods can be observed. Mounding leads to significantly deeper root system of $P$. sylvestris. Mounded sites have less competition for sunlight than trenched sites, and also provide dryer soil conditions. These factors could be the cause of roots reaching deeper for water in mounds. The most important finding of this study is that coarse roots are more evenly radially oriented when planted in mounds thus providing more stable further development. In addition, this study has shown that already during the first years after planting tree roots penetrate through the mound, therefore securing the tree in the soil underneath it. This has been one of the concerns regarding mounding. Due to different species specific properties, $P$. sylvestris roots grow through the mound slightly faster than $P$. abies.

When planting in disc trenched sites to provide most beneficial conditions for tree development it is crucial to choose advantageous direction of the furrows in relation to cardinal points (to maximize sunlight accessibility) and dominant winds (Burton et al. 2000). This study emphasizes the importance of the latter factor. Orientation of coarse roots determines tree resistance to strong winds and storms, therefore, given the unevenly distributed roots found in trenched sites, it would be advised to consider leading wind direction when making furrows. This is especially crucial when regenerating forests with species susceptible to windfalls, such as $P$. abies (Pellikka and Järvenpää 2003). These root distribution and wind resistance relations require further study in older forest stands. There are three main positions where a tree could be planted in disc trenched site-in the base of the furrow, in the hinge or on the berm (Burton et al. 2000). The distribution of roots of trees planted at the base or on berm of the trench could result in different root distribution than found in this study. These planting positions offer space in all directions for roots to expand more 


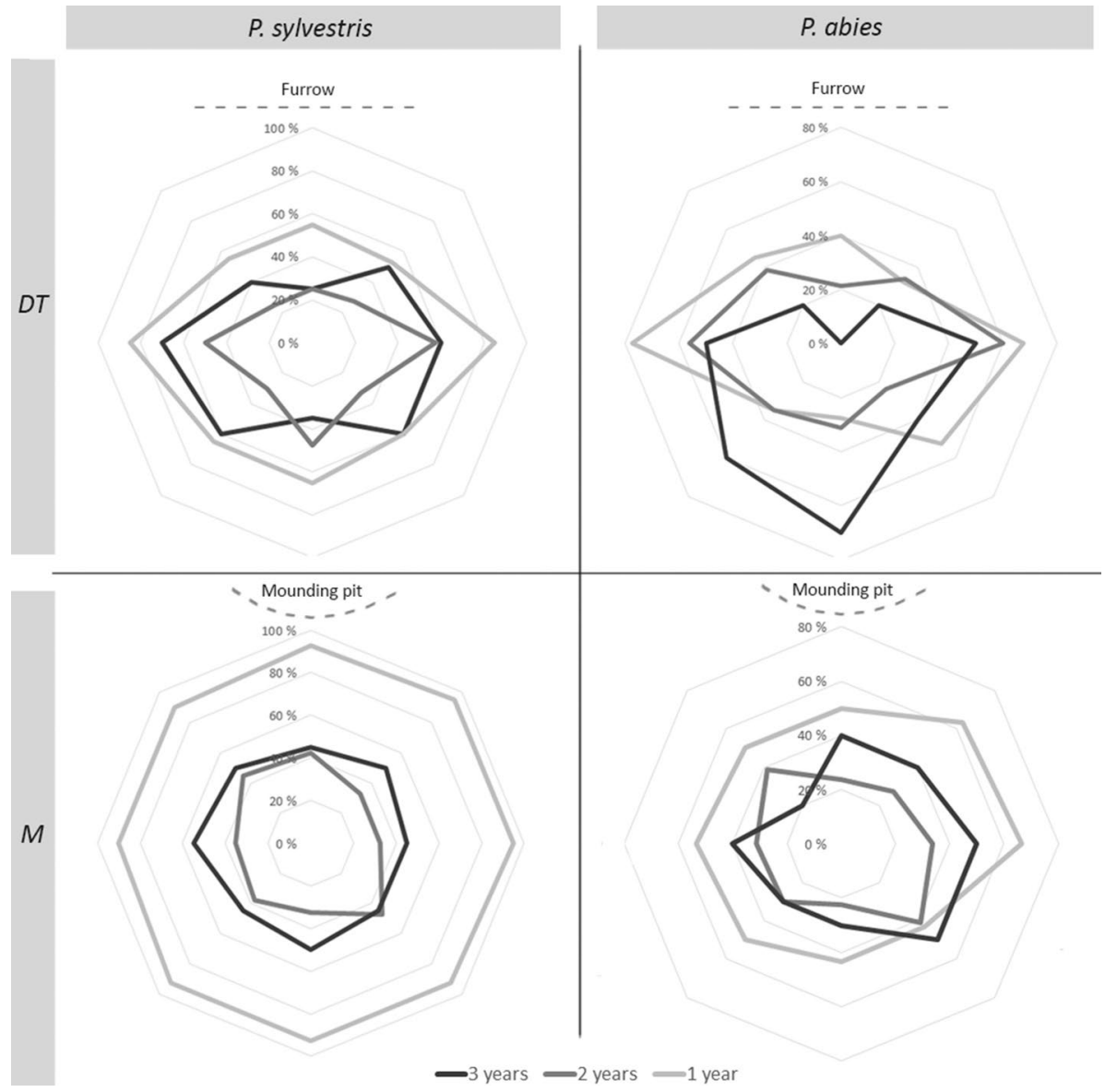

Fig. 5 Pinus sylvestris and Picea abies coarse root orientation in relation to furrow direction after 1, 2 and 3 growing seasons. ("Furrow" and "Mounding pit" represent the location of furrow and mounding pit in relation to tree). Percentage shows trees with roots in particular direction out of all measured trees

radially. Planting on the berm provides similar conditions as planning on mounds. However, planting depends on trenching machinery used and planting on the hinge provides more drought resistance in early years of growth (Mangalis 1989).

Concerning the interaction between tree species and soil preparation method, it seems that development of $P$. sylvestris is more responsive to soil preparation method.

This study found that, in the early stages of forest stand development, the main influence of soil preparation method used is evident in root development of seedlings.

Acknowledgements This study was a part of a research project Development of decision support tool for prognosis of storm damages in forest stands on peat soils (No 1.1.1.1/16/A/260) funded by European Regional Development Fund. And we would also like to thank JSC "Latvian State Forests" for funding and access to the used study sites.

Open Access This article is licensed under a Creative Commons Attribution 4.0 International License, which permits use, sharing, adaptation, distribution and reproduction in any medium or format, as long as you give appropriate credit to the original author(s) and the source, provide a link to the Creative 
Commons licence, and indicate if changes were made. The images or other third party material in this article are included in the article's Creative Commons licence, unless indicated otherwise in a credit line to the material. If material is not included in the article's Creative Commons licence and your intended use is not permitted by statutory regulation or exceeds the permitted use, you will need to obtain permission directly from the copyright holder. To view a copy of this licence, visit http://creativecommons.org/licen ses/by/4.0/.

\section{References}

Bates D, Maechler M, Bolker B, Walker S (2015) Fitting linear mixed-effects models using lme4. J Stat Softw 67(1):1-48

Burton P, Bedford L, Goldstein M, Osberg M (2000) Effects of disk trench orientation and planting spot position on the ten-year performance of lodgepole pine. New For 20(1):23-44

Fox J, Weisberg S (2011) An R companion to applied regression, 2nd edn. Sage, Thousand Oaks

Gemmel P, Nilsson U, Welander T (1996) Development of oak and beech seedlings planted under varying shelterwood densities and with different site preparation methods in southern Sweden. New For 12(2):141-161

Goulet F (1995) Frost heaving of forest tree seedlings: a review. New For 9(1):67-94

Haeussler S (1989) Mounding for site preparation. Topic summary for the operational forest. Queen's Printer for British Columbia, Victoria

Heiskanen J, Saksa T, Luoranen J (2013) Soil preparation method affects outplanting success of Norway spruce container seedlings on till soils susceptible to frost heave. Silva Fenn 47(1):1-17

Löf M, Dey DC, Navarro RM, Jacobs DF (2012) Mechanical site preparation for forest restoration. New For 43(5-6):825-848

Luoranen J, Rikala R (2013) Field performance of Scots pine (Pinus sylvestris L.) seedlings planted in disc trenched or mounded sites over an extended planting season. New For 44(2):147-162

Luoranen J, Viiri H (2012) Soil preparation reduces pine weevil (Hylobius abietis (L.)) damage on both peatland and mineral soil sites one year after planting. Silva Fenn 46(1):151-161

Mangalis I (1989) Meža kultūras. "Zvaigzne”. p 348

Mjöfors K, Strömgren M, Nohrstedt H, Johansson M, Gärdenä AI (2017) Indications that site preparation increases forest ecosystem carbon stocks in the long term. Scand J For Res 32(8):1-9

Nieminen JK, Räisänen M, Haimi J (2012) Spot mounding and granulated wood ash increase inorganic N availability and alter key components of the soil food web in clearcut Norway spruce forests. For Ecol Manag 263:24-30

Örlander G, Gemmel P, Hunt J (1990) Site preparation: a Swedish overview. FRDA Report 105

Pearson M, Saarinen M, Minkkinen K, Silvan N, Laine J (2011) Mounding and scalping prior to reforestation of hydrologically sensitive deep-peated sites: factors behind Scots pine regeneration success. Silva Fenn 45(4):647-667

Pellikka P, Järvenpää E (2003) Forest stand characteristics and wind and snow induced forest damage in Boreal Forests. In: Proceedings of the international conference on wind effects on trees, University of Karlsruhe, Germany

Pennanen T, Heiskanen J, Korkama T (2005) Dynamics of ectomycorrhizal fungi and growth of Norway spruce seedlings after planting on a mounded forest clearcut. For Ecol Manag 213:243-252

Petersson M, Örlander G, Nordlander G (2005) Soil features affecting damage to conifer seedlings by the pine weevil Hylobius abietis. Forestry 78:83-92

Pontey W (1808) The profitable planter: a treatise on the theory and practice of planting forest trees, in every description of soil and situation; more particularly on elevated sites, barren heaths, rocky soils, \&c., including directions for the planting and management of permanent screens; with useful hints on shelter and ornament, 2nd ed. Printed for the author by T. Smart, Huddersfield

R Core Team (2017) R: A language and environment for statistical computing. R Foundation for Statistical Computing, Vienna, Austria

Saksa T, Heiskanen J, Miina J, Tuomola J, Kolstrom T (2005) Multilevel modelling of height growth in young Norway spruce plantations in southern Finland. Silva Fenn 39(1):143-153

Sutton RF (1993) Mounding site preparation: a review of European and North American experience. New For 7:151-192

Uotila K, Rantala J, Saksa T, Harstela P (2010) Effect of soil preparation method on economic result of Norway spruce regeneration chain. Silva Fenn 44:511-524

Zālītis P, Jansons J (2013) Latvijas meža tipolog̣ija un tāssākotne. Daugavpils Akadēmiskais apgāds "Saule", p 168 